\title{
Research on the Image Perception of Shaoguan Tourism Food Based on Kelly Grid Technology
}

\author{
Li Yanfen ${ }^{1, *}$ \\ Guangzhou International Economics College, Baiyun District, Guangzhou City, Guangdong Province, China
}

\begin{abstract}
This study takes Shaoguan City, Guangdong Province as an example to study tourists' perception of local tourist food image. The research method uses the Kelly grid technique. Through interviews with 24 tourists who have travelled to Shaoguan, 36 key constructs are obtained, and they are divided into cognitive and emotional constructs. Seven final representative constructs are presented. After sub-analysis, it was found that Shaoguan's tourism food development is lagging behind, the food environment needs to be improved, and the lack of representative food in the city, etc., and proposed to establish representative tourism food, improve dietary hygiene awareness, and use the Internet to increase publicity and other optimization development suggestions.
\end{abstract}

\section{Introduction}

In 2021, due to the impact of the new crown pneumonia epidemic, international travel will be restricted, and domestic tourism and short-distance travel will increase during the normalization and control phase of the epidemic in China.

Shaoguan is located in the northern part of Guangdong Province, and Shaoguan has unique tourism resources. Shaoguan Danxia Mountain, one of the four famous mountains in Guangdong, is the only world natural heritage in Guangdong Province; Shikengkong is the highest peak in Guangdong; Nanhua Temple is a famous Buddhist temple in Guangdong. Shaoguan tourism has good development potential. The "Decision on Further Promoting the Revitalization and Development of the East, West and North of Guangdong" and the implementation of the "Decision of the CPC Guangdong Provincial Committee and the People's Government of Guangdong Province on Further Promoting the Revitalization and Development of the North, East and West of Guangdong" will be implemented. Policies such as the "Plan", "Shaoguan Tourism Development Master Plan", and "Several Policy Measures on Actively Responding to the Impact of the New Coronary Pneumonia Epidemic, Promoting the Stable and Healthy Development of Culture, Tourism and Sports and Expanding Market Consumption" also propose to vigorously develop Shaoguan tourism.

"Food, housing, transportation, travel, shopping, and entertainment" are the six elements of tourism. Food is an important and indispensable part of tourism and an important perception object of tourist destinations. From the perspective of tourism resources, food is an important tourism resource, which can increase tourism attractiveness; from the perspective of tourism economy, tourism food can increase tourism income; from the perspective of tourists, tourism food can enrich the tourism experience.

Therefore, this research starts with tourist food, analyzes tourists' perception of Shaoguan's food image, finds problems, finds out countermeasures, and improves the tourist attraction of Shaoguan.

\section{Literature review}

The study of tourism image in foreign countries is earlier than that in China. In the 1970s, HUNT J D, MAYO Edward and GUNN Clare began to study tourism image. Looking at the China Knowledge Base, China's research on tourism image originated in the 1980s, and the number of related studies has continued to rise in 2000 , becoming a tourism research hotspot. Through the research on Shaoguan's tourism image through HowNet, 6 documents were obtained. Luo Meijuan and others used Ctrip as a research sample to study Shaoguan's image perception as a tourist destination through content analysis ${ }^{1}$. Other scholars often put forward development suggestions from the macro perspective.

The research on tourist cuisine started relatively late. In 2000, the first international conference on local cuisine and tourism was held in Cyprus. Many articles at the conference proposed to make local cuisine a unique attraction for tourist destinations ${ }^{2}$. Quan S, Wang N. It is believed that diet can constitute the peak experience and supportive experience of tourists ${ }^{3}$. Tikkanen believes that the food in tourism can simultaneously meet the five levels of needs in Maslow's hierarchy of needs ${ }^{4}$. The research process of food tourism is relatively slow in China, mainly based on local empirical research, such as Sichuan, Chongqing, Xi'an and other cities. Zhang Xiaoping 
believes that Shaoguan has rich food culture resources and is suitable for the development of food culture and leisure tourism ${ }^{5}$.

Judging from the publication time and quantity of literature, there is a lack of research on Shaoguan's tourism image and tourism food, and scholars have not paid full attention to it. Judging from the content of the literature, scholars agree with the importance of tourist food in the travel process. However, in China, the current research areas of tourist cuisine are mainly developed tourist cities, and there is less research on underdeveloped areas. The research theme is mainly the development strategy of food, and less research is conducted from the perspective of tourism image.

\section{Research method}

\subsection{Theoretical perspective}

Repertory Grid Analysis was proposed by American psychologist George Kelly in the 1950s, and its basic theory is the theory of personal construction ${ }^{6}$. Repertory Grid Analysis is generally translated as Kelly grid technique, or repertory grid method in China. Since the 1870 s, Kelly's grid technology has been used in the field of urban tourism image research.

In foreign research, Lincoln, James, Whyte. uses Kelly grid technology to study the image of North American cruise destinations from the perspective of cruise passengers ${ }^{7}$. Chang R C Y, Mak A H N. Using the Kelly grid technique, 50 international tourists were interviewed and studied, 46 attributes of food tourism were summarized, and they were classified into 7 categories $^{8}$. Naoi T, Airey D, Iijima S, et al. used Repertory Grid Analysis as one of the research methods to explore the complexity of tourist evaluation in historical districts 9 .

In domestic research, Chen Xiaolian used the Kelly grid technique to obtain typical elements of Macau food tourism through preliminary and in-depth interviews, and obtained the three final structural concepts of "satisfaction", "richness" and "pleasure", and proposed development countermeasures for this ${ }^{10}$. Tan Jianping conducted classification and comparative analysis of relevant domestic and foreign documents, and proposed the advantages of Kelly grid technology in the study of tourism image research, such as the restrictive, flexible and convenient research ${ }^{11}$. Tan Jianping combined Kelly grid technique and questionnaire survey method to study the festival image of Shenzhen Nanshan Litchi Cultural Tourism Festival ${ }^{12}$.

On the whole, the research and application of Repertory Grid Analysis in foreign countries is earlier than that in China, and there are more researches on food tourism than in China.

\subsection{Data collection and analysis}

\subsubsection{Selection of research samples}

Investigate the perception of Shaoguan's food tourism image by tourists who have been to Shaoguan, Guangdong through interviews. The number of interviewees was 24, half for men and women, aged 15 to 65 , and each interview time was about 15 minutes.

In order to improve the accuracy of the research, the interviewees are limited to tourists who have traveled to Shaoguan within 5 years to prevent tourists from forgetting and memory errors due to excessive travel time, which affects the accuracy of the data.

\subsubsection{Data collection}

Affected by the epidemic, in order to ensure safety as much as possible, the interviews in this study were mainly conducted via telephone or the Internet.

The concept of this research was put forward by the tourists during the interview. The first-hand information obtained by the researcher through the interview was sorted out by using Kelly grid technique and content analysis method.

\subsubsection{Construct extraction and sorting}

A total of 123 constructs were obtained from the interview. In the interview process, the tourist construct will have repeated meanings. For example, when describing the overall feeling of Shaoguan cuisine, the interviewees used the words "delicious" and "delicious" to express differently, but basically the same meaning, so they used the term "delicious" to generalize; when describing the specific taste, the interviewees used the words "delicious" and "delicious" to express differently. Through content analysis, compilation, merging and repetition, and filtering of constructs that only appeared once, 38 key constructs were finally obtained.

Table1. Frequency table of perception constructs of Shaoguan gourmet image

\begin{tabular}{|c|c|c|c|c|c|}
\hline $\begin{array}{c}\text { Numb } \\
\text {-er }\end{array}$ & Construct & $\begin{array}{l}\text { Frequ } \\
\text {-ency }\end{array}$ & $\begin{array}{c}\text { Numb } \\
\text {-er }\end{array}$ & Construct & $\begin{array}{l}\text { Frequ } \\
\text {-ency }\end{array}$ \\
\hline 1 & $\begin{array}{l}\text { Enough } \\
\text { serving }\end{array}$ & 18 & 20 & Better air & 4 \\
\hline 2 & Cheaper & 18 & 21 & $\begin{array}{c}\text { Maba oil } \\
\text { sticky rice }\end{array}$ & 3 \\
\hline 3 & Fresh & 14 & 22 & $\begin{array}{c}\text { Plum } \\
\text { Vegetable } \\
\text { Meatloaf }\end{array}$ & 3 \\
\hline 4 & Delicious & 12 & 23 & $\begin{array}{l}\text { Cold water } \\
\text { pork belly }\end{array}$ & 3 \\
\hline 5 & $\begin{array}{c}\text { Sanitary } \\
\text { conditions } \\
\text { are average }\end{array}$ & 10 & 24 & $\begin{array}{l}\text { Glutinous } \\
\text { rice wine }\end{array}$ & 2 \\
\hline 6 & $\begin{array}{l}\text { Decoration } \\
\text { is ordinary }\end{array}$ & 9 & 25 & $\begin{array}{l}\text { Reservoir } \\
\text { fish }\end{array}$ & 2 \\
\hline 7 & $\begin{array}{c}\text { Danxia } \\
\text { Mountain }\end{array}$ & 8 & 26 & $\begin{array}{l}\text { Eagle- } \\
\text { billed } \\
\text { Peach } \\
\end{array}$ & 2 \\
\hline 8 & $\begin{array}{c}\text { People are } \\
\text { Simple }\end{array}$ & 7 & 27 & $\begin{array}{l}\text { River } \\
\text { Prawn } \\
\end{array}$ & 2 \\
\hline 9 & $\begin{array}{c}\text { Bainian } \\
\text { East Street } \\
\text { Milk Tea }\end{array}$ & 6 & 28 & $\begin{array}{c}\text { Local } \\
\text { Chicken }\end{array}$ & 2 \\
\hline
\end{tabular}




\begin{tabular}{|c|c|c|c|c|c|}
\hline 10 & Pork & 6 & 29 & Stinky tofu & 2 \\
\hline 11 & Authentic & 6 & 30 & $\begin{array}{l}\text { Copper } \\
\text { Spoon } \\
\text { Cake }\end{array}$ & 2 \\
\hline 12 & $\begin{array}{l}\text { Sanhua } \\
\text { plum }\end{array}$ & 6 & 31 & $\begin{array}{c}\text { Longer } \\
\text { distance }\end{array}$ & 2 \\
\hline 13 & tofu & 5 & 32 & $\begin{array}{l}\text { glutinous } \\
\text { rice cake }\end{array}$ & 2 \\
\hline 14 & $\begin{array}{l}\text { Nanhua } \\
\text { Temple }\end{array}$ & 3 & 33 & $\begin{array}{c}\text { Chili } \\
\text { Sauce }\end{array}$ & 2 \\
\hline 15 & $\begin{array}{l}\text { Tomato } \\
\text { beef }\end{array}$ & 3 & 34 & $\begin{array}{c}\text { Lechang } \\
\text { Marty }\end{array}$ & 2 \\
\hline 16 & Escargot & 3 & 35 & Greens & 2 \\
\hline 17 & $\begin{array}{l}\text { Buddhist } \\
\text { food }\end{array}$ & 3 & 36 & $\begin{array}{c}\text { Changba } \\
\text { Shatian } \\
\text { Pomelo }\end{array}$ & 2 \\
\hline 18 & $\begin{array}{c}\text { Nanxiong } \\
\text { Sour } \\
\text { Bamboo } \\
\text { Shoot } \\
\text { Duck } \\
\end{array}$ & 3 & 37 & $\begin{array}{l}\text { Eagle- } \\
\text { billed } \\
\text { Peach }\end{array}$ & 2 \\
\hline 19 & Spicy & 3 & 38 & $\begin{array}{l}\text { Golden } \\
\text { Plum }\end{array}$ & 2 \\
\hline
\end{tabular}

As the number of constructs proposed by the interviewees increases, the repetitiveness of the constructs will increase. When the new construct increases to zero, it means that the construct proposed by the visitor is typical.

Drawing lessons from the classification of tourism images by Baloglu and Mccleary, this study categorizes 38 key constructs of tourists' travel food in Shaoguan according to the "cognition-emotion" classification framework, which is divided into cognitive and emotional constructs. The constructs include specific Shaoguan food and eating places, and the emotional constructs include feelings about food and the eating environment ${ }^{13}$.

Table2. Classification table of Shaoguan's tourist food constructs

\begin{tabular}{|c|c|c|c|}
\hline $\begin{array}{c}\text { Construct } \\
\text { type }\end{array}$ & $\begin{array}{c}\text { Construct } \\
\text { category }\end{array}$ & $\begin{array}{c}\text { Number of } \\
\text { constructs }\end{array}$ & $\begin{array}{c}\text { Highest } \\
\text { frequency } \\
\text { construct }\end{array}$ \\
\hline $\begin{array}{c}\text { Cognitive } \\
\text { Construct }\end{array}$ & Food & 25 & $\begin{array}{c}\text { Centennial } \\
\text { East Street } \\
\text { Milk Tea, } \\
\text { Pork }\end{array}$ \\
\cline { 2 - 4 } & Location & 7 & $\begin{array}{c}\text { Danxia } \\
\text { Mountain }\end{array}$ \\
\hline \multirow{2}{*}{$\begin{array}{c}\text { Emotional } \\
\text { constructs }\end{array}$} & Food & 6 & $\begin{array}{c}\text { servings are } \\
\text { enough }\end{array}$ \\
\cline { 2 - 4 } & $\begin{array}{c}\text { Environm } \\
\text { ent }\end{array}$ & 4 & Sanitary \\
\hline
\end{tabular}

\subsubsection{Constructive analysis}

In terms of cognitive constructs, Shaoguan has more delicacies. Tourists have the deepest perception of Shaoguan's specific foods are Bainian Dongjie milk tea and pork meat, and the deepest perception of places is Danxia Mountain. In terms of emotional constructs, the deepest feeling for food is weight, the deepest taste is spicy, the deepest perception of people in Shaoguan is simplicity, and the deepest perception of the environment is hygiene.

Drawing on the 28th law proposed by the Italian economist Pareto at the end of the 19th century and the beginning of the 20th century, this study selects $20 \%$ of the key constructs in Table 1 according to the frequency of constructs proposed by tourists, that is, 7 constructs as high-frequency constructs, respectively Yes: sufficient portion, cheaper, fresh, delicious, general sanitation, general restaurant environment, Danxia Mountain, etc., which represent the typical perception of tourists on the image of Shaoguan's tourist food.

\section{Conclusion and discussion}

\subsection{Conclusion}

Through the analysis of the constructs, the advantages and problems of Shaoguan's tourist food are drawn.

\subsubsection{Advantages of Shaoguan's tourist food}

There are three main advantages.

First, tourists' overall imagination and perception of Shaoguan cuisine are positive and positive comments. It is found in the frequency table that more than

The constructs that counted half of the people were positive reviews, and the evaluations in the final 7 constructs were also positive reviews.

Second, Shaoguan is rich in food resources. Visitors proposed a wide range of food, and 25 food structures were proposed after screening.

Nian, it proves that Shaoguan's tourist food has development potential.

Third, Shaoguan tourist food is cost-effective. This boils down to the outstanding feature of Shaoguan's tourist cuisine, which is also different from the first-line.

The important image perception of tourist food in central cities.

\subsubsection{Problems in Shaoguan's tourist food}

There are three main problems.

First, the tourism products are single, and the development of tourism food is lagging behind. Shaoguan is dominated by traditional sightseeing tours, and Danxia Mountain is well-known, but its gastronomic tourism resources have not been fully developed, the tourist food attraction is insufficient, and tourists do not perceive it deeply. The survey found that even if the topic is Shaoguan tourist food, the first reaction of many tourists is Danxia Mountain, but they can't name the relevant representative food.

Second, the insufficient development of tourism food resources has affected tourists' good impression of Shaoguan tourism food. Eating environment,

The restaurant decoration and hygiene issues need to be improved.

Third, there is no representative food of cities with high tourist perception, the degree of marketization of tourist food is not high, and the products are refined insufficient. In Table 1, tourists have scattered perceptions of specific foods, and the constructs are not frequently proposed. 


\subsection{Discussion}

In the process of normalizing the control of the epidemic in 2021, the tourism industry has gradually recovered, and tourism within the province has become a hot topic. It is of immediate and long-term significance to improve Shaoguan's tourism competitiveness and fully tap tourism resources. Based on the research conclusions, this research puts forward discussions and suggestions for the problems of Shaoguan tourist food.

\subsubsection{With the help of typical tourism resources, establish representative tourism delicacies}

Shaoguan is rich in resources and products, but tourism in Danxia Mountain in Shaoguan is deeply rooted in the hearts of the people, and the development of related gastronomic resources has not been in place. We should take advantage of Danxia Mountain's tourism advantages, play the pioneering role of Danxia tourism, promote local specialties, and establish a model of Shaoguan tourism cuisine.

\subsubsection{The government intensifies management and publicity, and raises awareness of food hygiene}

The government and relevant departments and organizations should attach importance to environmental sanitation protection for tourism and catering, increase management and publicity, and promote environmental and sanitation education in villages and stores, combining rewards and punishments, and promoting them through multiple channels.

\subsubsection{Give full play to the long-tail effect and leverage the network to increase publicity}

Shaoguan's atypical food constitutes the majority of Shaoguan's food resources and belongs to long-tail products. Such scattered resources can play the role of low-cost Internet marketing, emphasize characteristics, and increase visibility and niche customer audiences.

\section{References}

1. Luo Meijuan, Qi Mingde, Zhang Taotao. Research on Shaoguan Tourist Destination Image Perception Based on Internet Travel Notes[J]. Journal of Shaoguan University,2017,38(04):80-87.

2. Cohen E. Avieli N. Food in Tourism: Attraction and impediment $[\mathrm{J}]$. Annals of Tourism Research, 2004, 31(4): 755-778.

3. Quan S, Wang N. Towards a structural model of the tourist experience: An illustration from food experience in tourism $[\mathrm{J}]$. Tourism Management, 2004, 25 (3): 297-305.

4. Tikkanen I. Maslow's hierarchy and food tourism in Finland: Five cases [J] . British Food Journal, 2007, 109 (9): 721-734.
5. Zhang Xiaoping. On the development of Shaoguan food culture tourism resources[J]. Journal of Shaoguan University,2014,35(11):129-132.

6. Kelli G A. Atheory of personality: the psychology of personalconstructs[M], New York W. W. Norton and Company, 1963.

7. Lincoln, James, Whyte. Eliciting cruise destination attributes using repertory grid analysis[J]. Journal of Destination Marketing \& Management on SciVerse ScienceDirect, 2018, 10:172-180.

8. Chang $\mathrm{R}$ C Y, Mak A H N. Understanding gastronomic image from tourists' perspective: A repertory grid approach[J]. Tourism Management, 2018, 68(OCT.):89-100.

9. Naoi T, Airey D, Iijima S, et al. Towards a theory of visitors' evaluation of historical districts as tourism destinations: Frameworks and methods[J]. Journal of Business Research, 2007, 60(4):396-400.

10. Chen Xiaolian. Analysis of Typical Elements of Macau Food Tourism[J].China Business, 2013(06): 121-123.

11. Tan Jianping. Overview of the application of Kelly's grid method in tourism image research[J].Business,2015(17):272-273+206.

12. Tan Jianping. Research on the measurement of traditional property-type festival image[D]. South China University of Technology, 2013.

13. Baloglu S, Mccleary K W. International Pleasure Travelers' Images of Four Mediterranean Destinations: a Comparison of Visitors and Nonvisitors [J] . Journal of Travel Research,1999 (2): 144-152. 